\title{
DEVELOPING ROBOT TRANSPORTER LEARNING MEDIA TO LEARN MICROCONTROLLER
}

\author{
I Gusti Putu Asto Buditjahjanto ${ }^{1 *}$, Chandra Ainur Rizqi ${ }^{1}$, Bambang Suprianto ${ }^{1}$ \\ ${ }^{1}$ Universitas Negeri Surabaya \\ Jl. Ketintang, Gayungan, Kota Surabaya, Jawa Timur 60231, Indonesia
}

\begin{abstract}
Learning media play a role in bridging the interaction between the teacher and students. Using learning media can help students to understand the material delivered by the teacher more efficiently. Al Kholiliyah, a Vocational High School in Bangkalan, Indonesia, still lacks interactive learning media to motivate students in learning. The robot transporter as an interactive learning medium can be applied to solve the lack of learning media that engage students in learning. The purpose of this study is to analyze the validity of the robot transporter as learning media, to analyze the validity of the learning plan (a syllabus, a lesson plan, a student worksheet) of robot transporter learning media, and to analyze the student response of the usage robot transporter learning media. The validation results of the robot transporter learning media show that the value of the validity is 3.89, categorized as very valid. The validity of the syllabus is 3.78, categorized as very valid, the validity of the lesson plan is 3.88, categorized as very valid, and the validity of the student worksheets is 3.89, categorized as very valid. The results of student responses show that there are two responses: strongly agree and 28 responses with the category of agree. Based on the robot transporter validity, the learning plan validity, and the student response, it can be concluded that the robot transporter can be used in the teaching and learning process.
\end{abstract}

Keywords: robot transporter, learning media, validation, microprocessor

How to cite: Buditjahjanto, I., Rizqi, C., \& Suprianto, B. (2020). Developing robot transporter learning media to learn microcontroller. Jurnal Pendidikan Vokasi, 10(3), 270281. doi:https://doi.org/10.21831/jpv.v10i3.34140

*Corresponding Author: I Gusti Putu Asto Buditjahjanto@asto@unesa.ac.id

Department of Electrical Engineering, Faculty of Engineering, Universitas Negeri Surabaya J1. Ketintang, Gayungan, Kota Surabaya, Jawa Timur 60231, Indonesia 


\section{INTRODUCTION}

The learning media as a part of the communication process holds an important role in the teaching-learning process. Learning media play a role in bridging the interaction between the teacher and students. The interaction with learning media helps students to understand the learning material delivered by the teacher more effectively (Sadiman, 2010). While listening to learning material, sometimes, there are various explanations that students cannot understand very well. Thus, more interactive learning material is needed. For example, when the teacher teaches the basics of electronics, then he/she uses learning media such as visual diagrams, photos, videos, or the prototype of the object, students will be able to capture the presented material very well (Mayer, 2001).

The development of learning media is one of the steps to improve the education system. Learning media is defined as tools that help during the teaching and learning process (Apriyus et al., 2020). Learning media has a broad scope, including people, material, or study, that creates a situation where students can acquire knowledge, skills, or attitudes (Daryanto, 2010). The form of learning media can consist of hardware, such as computers, TVs, projectors, and the software used on these hardware devices (Baharuddin \& Daulay, 2017; Sarwandi et al., 2019). In other words, learning media can be used to generate thoughts, feelings, attention, abilities, and skills of students, thus encouraging the learning process (Suryani \& Agung, 2012).

SMK Al Kholiliyah, a private vocational high school in Bangkalan, East Java, Indonesia has problems in the teaching-learning process in microcontroller subject, namely in the lack of learning media, students' low motivation and learning outcomes in learning microcontroller because of the subject's difficulty level. Microcontroller subject aims to provide knowledge and skills for students that can be applied to society. Meanwhile, in the basic competitions of microcontroller subject, students are expected to be able to make a simple application program and demonstrate the program. Thus, proper learning media that can help to solve those problems are needed. The use of proper learning media can help students gain their learning motivation (Haryawan \& Prayogo, 2017).

Robot is a medium that can attract students' attention, motivate students to learn new things about robots, and can be used for interactive learning (Lee et al., 2012; Sena \& Howard, 2019; Lanz et al., 2019). Most robot's main components are electronic circuit components which function to move the robot, communicate with users, and execute computer programs implanted in the robot (Baba, 2020; Li et al., 2018; Negri, et al., 2019). In the learning process, students can use electronic circuit components to learn about their functions and how they work in robots. One type of robot that has simple components and can be used for learning in the class is the transporter robot. The transporter robot consists of several parts, namely a robot driving wheel, a clamp to pick up objects, and a microcontroller module. These parts can be used for learning some learning materials.

Teachers of SMK Al Kholiliyah recommended choosing the robot transporter as learning media because it has some advantages such as simplicity of robot design, the components are mostly easy to get and helping students to understand how to assemble a robot. This research studied robot transporter using microcontroller based on android applications. The robot transporter as learning media was used as a tool for students to learn the subject of a microcontroller to ease them to understand it. If their understanding of the microcontroller improves, then their learning outcome also increases. Based on that description, the purposes of this research are to analyze the validity of robot transporter learning media, to analyze the validity of the learning plan of robot transporter learning media, and to evaluate students' response to the usage of robot transporter learning media.

\section{RESEARCH METHOD}

\section{Research Design}

This research was to develop and to analyze the robot transporter as a learning medium and to analyze the validity of the learning plan and students' responses. The research and development (R\&D) method was used since it has detailed steps to develop a product and testing the validity, practicality, and effectiveness of the product appropriate with the objective of this research. The R\&D method used has some steps: potential and problems, data collection, product design, design validation, design revision, product testing, product revision, and product implementation. 
The subjects of this research were the students of SMK Al Kholiliyah, a private vocational high school in Bangkalan Indonesia. The number of students in the Department of Industrial Electronics Engineering at SMK Al Kholiliyah for class XII was 80 students. The samples were randomly selected from several students majoring in Industrial Electronics Engineering. The selection was random and did not differentiate between class and sex in sampling. The sample experimental class consisted of 30 students who were willing to participate.

The researchers made observations to the class X TEI 1 at SMK Al Kholiliyah. Observation results showed that the problem in that class was the lack of media to teach and learn in a microcontroller subject. Thus, developing learning media that can attract students' intention to learn microcontroller is needed. The robot transporter became an option to be a potential learning medium to attract students' intention and to motivate students because of its attractiveness. The data were collected using some instruments. Then, these instruments were used to obtain students' responses and to get the validity of the transporter robot learning media and the validity of the learning plan.

\section{Research Procedures}

The procedure of this research was started with creating the robot transporter as learning media. The development of the robot transporter was based on the needs of the teaching-learning process at SMK Al Kholiliyah. Before being implemented in the class, the robot transporter, and the learning plans that guide the teaching-learning process were validated by three experts. After getting validation and making revisions according to the experts' suggestions, then the robot transporter and learning plan can be implemented in the classroom. The next procedure was to measure the students' responses toward the usage of the robot transporter. This procedure was done to find out how big the role and benefits of the robot transporter were after applied in the class.

\section{Product Design}

This research built the robot transporter as learning media. Figure 1 shows the electronic parts of the robot transporter. This robot transporter consists of some electronic parts such as Bluetooth module, DC source, microcontroller ATMega8, and DC motor module. The Bluetooth Module acts as a medium communication between the ATMega8 Microcontroller on the transporter robot side and the side of the Android Smartphone user. The DC source supplies electricity to the ATMega8 Microcontroller and the DC Motor Module. The ATMega8 microcontroller contains some computer programs to move the robot transporter and also to move the robot clamp according to user commands controlled via an Android Smartphone. The DC motor module functions to drive two motors according to the computer programming from the ATMega8 microcontroller.

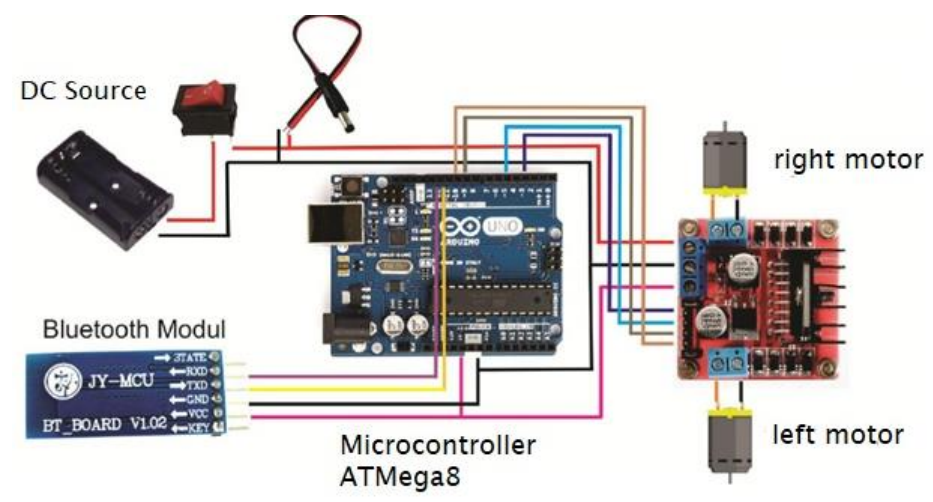

Figure 1. Electronic Parts of Robot Transporter

Figure 2 shows the software application of Bluetooth remote control installed on Android Smartphone. When the software application opened, the main menu appears and activates the Bluetooth to make a connection between the robot transporter and the Android Smartphone. After the Bluetooth is connected, each button on the software application can be used by sending instructions that are processed in the microcontroller to move the robot transporter or to clamp a thing. This ro- 
bot transporter consists of three main parts, namely a part to move the robot, a part of the main body, and a part of the clamp robot. Figure 3 shows the robot transporter as a learning media.

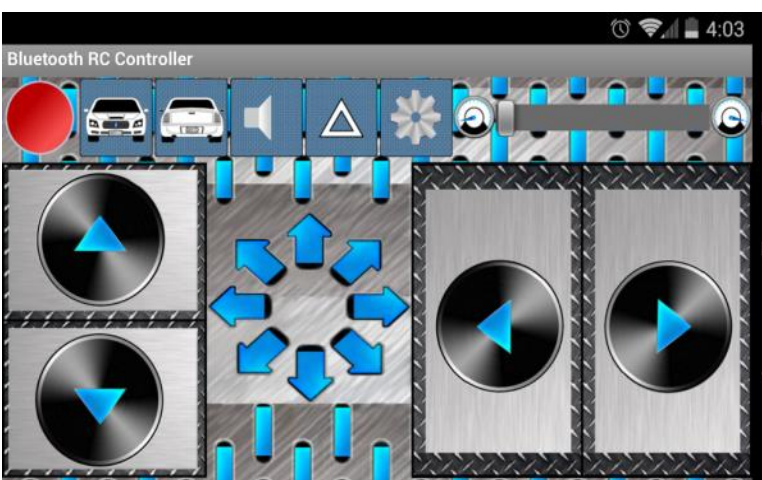

Figure 2. Display Bluetooth RC Controller on Smartphone

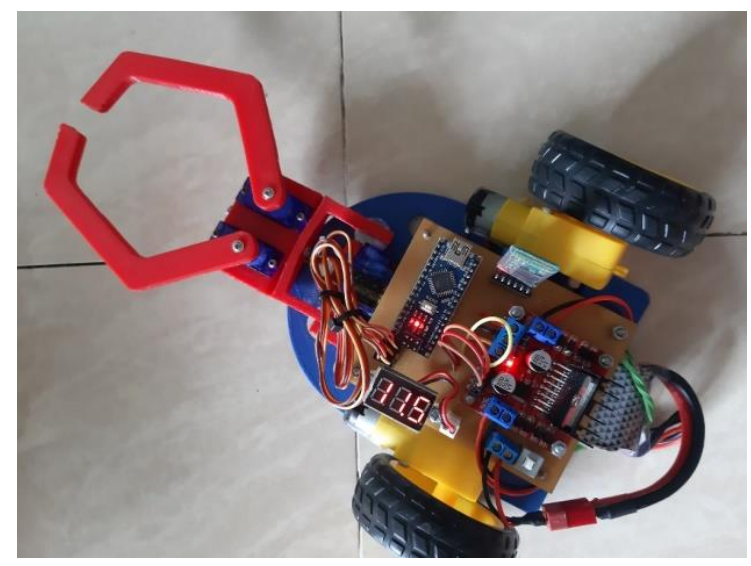

Figure 3. The Robot Transporter

\section{Instruments}

\section{Design Validation and Design Revision}

The next step was to develop some instruments to assess the validity of the robot transporter, whether it was valid or not. Three experts were selected based on their expertise to assess the validity of the robot transporter. The instruments compiled consist of the validation instrument of robot transporter, the validation instrument of robot transporter learning plan (syllabus, lesson plans, and student worksheets), and the validation instrument of student response. Table 1 shows the validation instrument of the robot transporter. This instrument consists of three constructs, namely content (eight indicators), feature format (nine indicators), and language (five indicators).

Table 1. Validation Instrument of Robot Transporter

\begin{tabular}{cl}
\hline No. & \\
\hline Content & Aspect / Indicator \\
1 & The learning material suitability with learning objectives. \\
2 & Suitability with students' thinking level. \\
3 & Completeness of the learning material. \\
4 & Learning material accuracy. \\
5 & Learning material is organized based on its structure. \\
6 & The material depth is based on its structure. \\
7 & The material suitability with the level of student development. \\
8 & The connectivity between the ongoing material with the previous material. \\
Feature Format \\
9 & Using harmless materials \\
10 & Easy material for assembly \\
11 & Tools are functioned according to the program \\
12 & Software is easy to obtain \\
13 & Software is easy to operate \\
14 & The spare part is easy to obtain \\
15 & The components compatibility with the material \\
16 & The presence of a Bluetooth feature \\
17 & The tool can function normally \\
Language & \\
18 & Language is easy to understand. \\
19 & Language according to general guidelines for Indonesian spelling. \\
20 & The language used can explain the material presented. \\
21 & Language suitability. \\
22 & Language in learning materials is communicative. \\
\hline
\end{tabular}


Table 2 presents the validation instrument of the syllabus. This instrument consists of 11 constructs, such as the identity of the education unit/school, subject identity, class/education level, main competencies, basic competencies, indicator, subject matter, learning, assessment, time allocation, and also learning resources. Therefore, the total number of indicators for all constructs is 30 items.

Table 2. Validation Instrument of the Syllabus

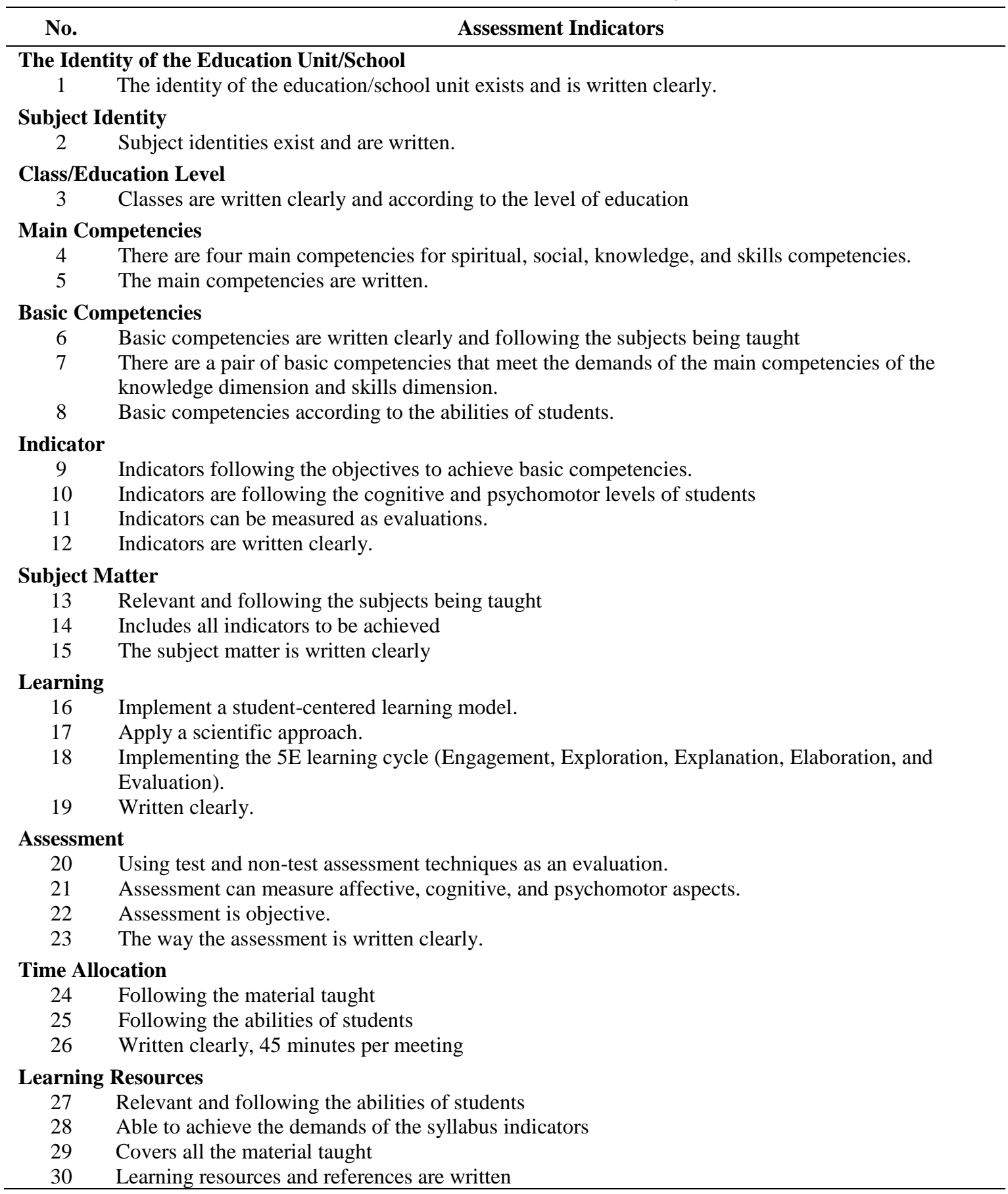

Table 3 presents the validation instrument of the robot transporter lesson plan. This validation instrument consists of eight constructs, such as lesson plan identity, indicator formulation, formulation of learning objectives, learning methods and scenarios, media and learning tools, learning materials and learning resources, authentic assessment, and also sentences and grammar. The total number of indicators for all constructs is 31 items. 
Table 4 shows the validation instrument of the robot transporter's students' worksheets. This validation instrument consists of six constructs, namely student worksheet identity, indicator formulation, formulation of learning objectives, instruction procedure, main aspects of student worksheets, and sentences and grammar. The total number of indicators for all constructs is 25 items.

Table 3. Validation Instrument of Robot Transporter Lesson Plan

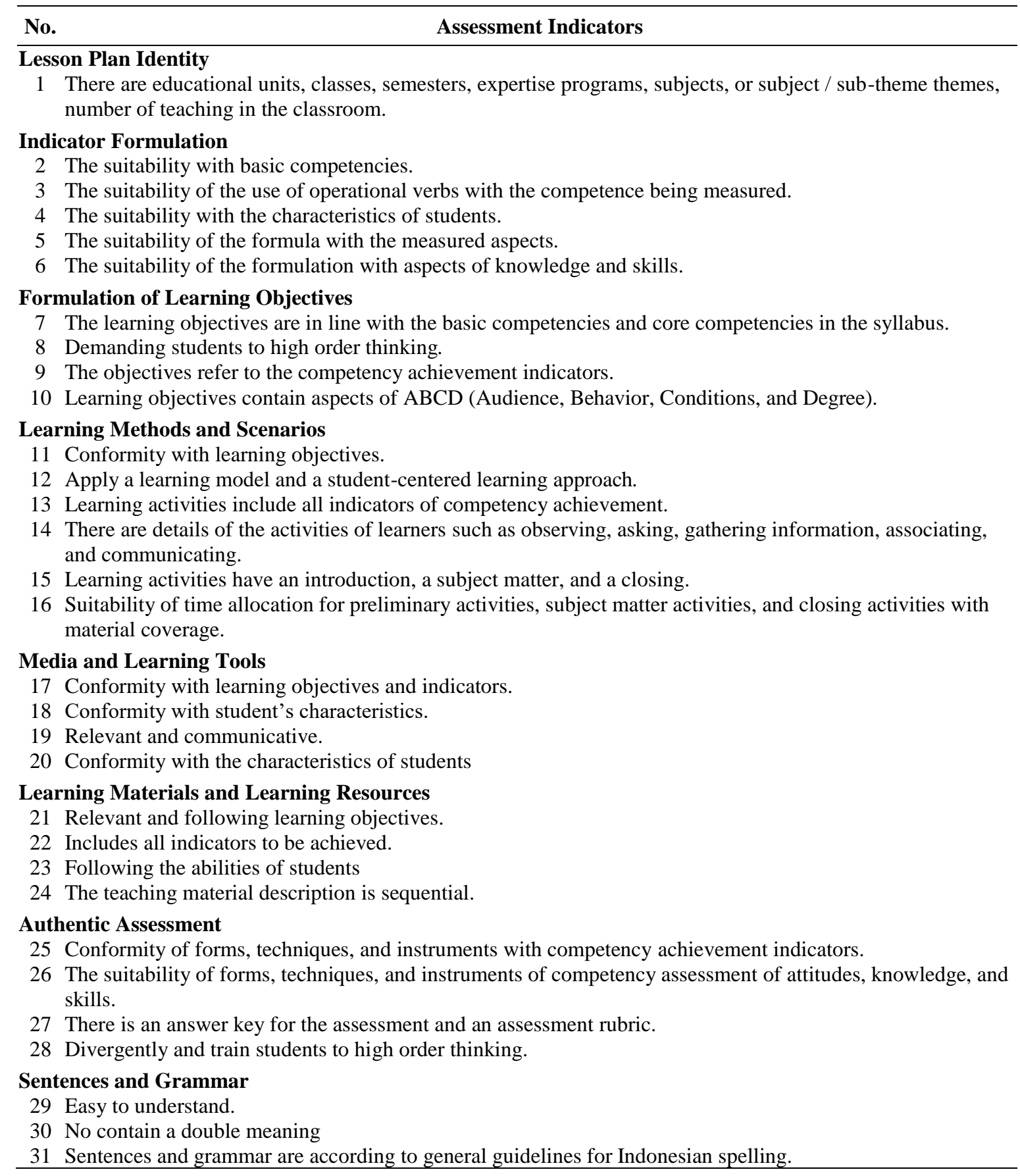

Table 5 shows the students' response validation instrument. This validation instrument consists of three constructs: language (six indicators), writing format and systematics (six indica-tors), and content quality (three indicators). The total number of indicators for all constructs is 15 items.

Validation of robot transporter was done by three experts consisting of two lecturers from Universitas Negeri Surabaya and one teacher from SMK Al Kholiliyah. The validator's assessment of the robot transporter refers to the indicators on the validation sheet with the assessment criteriaas follows (Akbar, 2013): 1 = not valid; $2=$ less valid; 3 = quite valid; $4=$ valid; and $5=$ very valid. 
276 - I Gusti Putu Asto Buditjahjanto, Chandra Ainur Rizqi, \& Bambang Suprianto

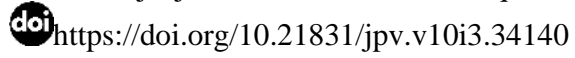

Table 4. Validation Instrument of Robot Transporter Students Worksheet

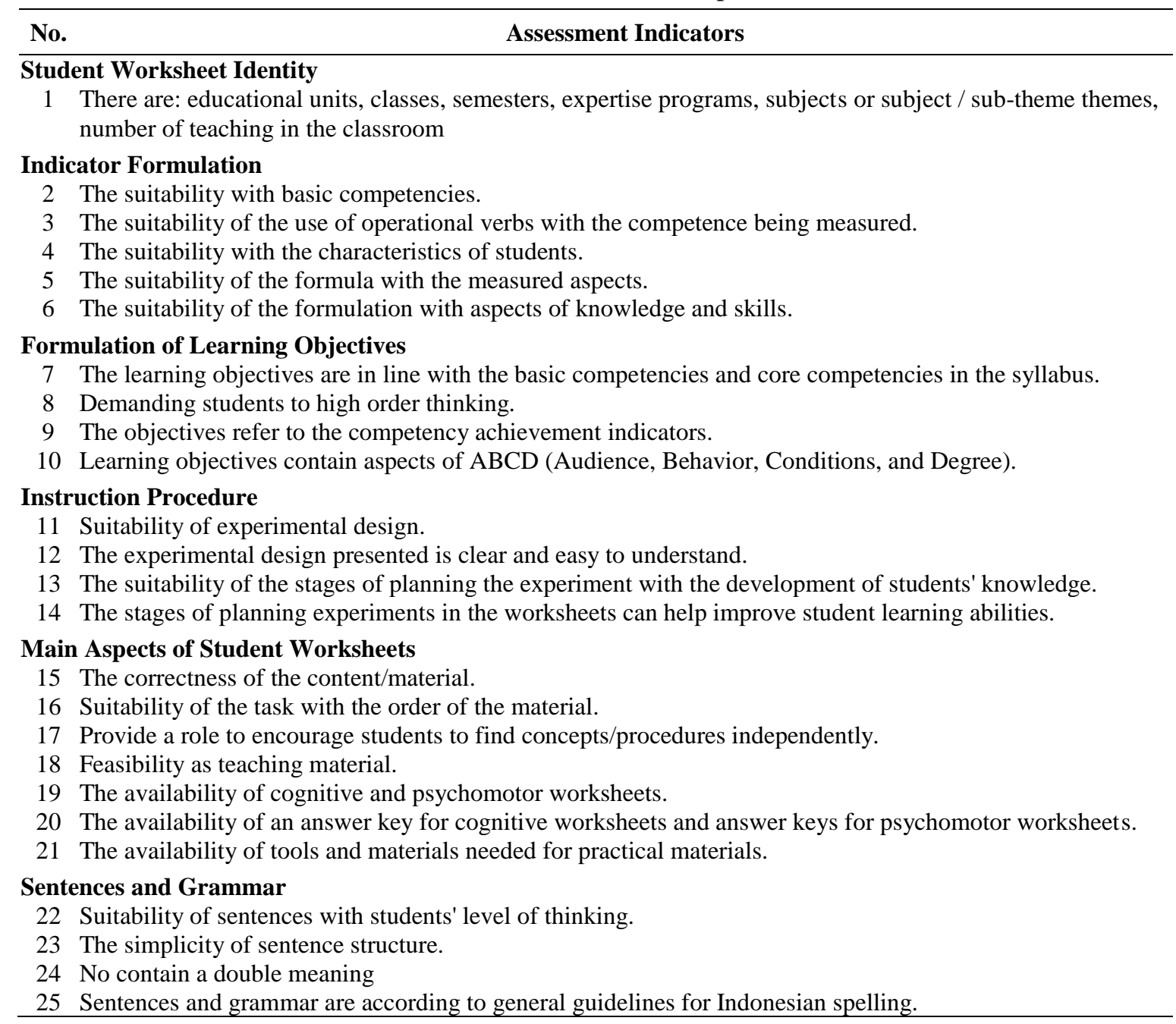

Table 5. Validation Instrument of Student Response

No. Assessment Indicators
Language
1. Readability
2. Grammatical correctness
3. The accuracy of the sentence structure
4. Use of language effectively and efficiently
5. The language used is communicative
6. The suitability of grammar with the age of the student
Writing Format and Systematics
1. Clarity of writing in instructions for filling student responses
2. Clarity of writing in student opinions indicators on the components asked in student response questionnaire
3. Clarity of writing in the novelty indicator for the components asked in the student response questionnaire
4. Clarity of writing in the indicator of the ease with which students understand the components asked in the
student response questionnaire
5. Clarity of writing in student interest indicators in the components asked in the student response questionnaire
6. The clarity of writing in the activity indicators carried out by the lecturer/teacher is related to the components
asked in the student response questionnaire
Content Quality
1. The correctness and appropriateness of the description contents of statements in student response questionnaire
2. The feasibility of a student response questionnaire as a learning tool
3. The suitability of the assessment criteria with the statements description in the student response questionnaire


Quantitative descriptive was used to analyze data from the validation result. The analyzing done by quantifying the average score of the validators assessment. This average score transformed into the assessment category as shown in Table 6 (Riduwan, 2012).

Table 6. Category of Instrument

\begin{tabular}{cc}
\hline Score & Category \\
\hline $3.6 \leq \mathrm{P} \leq 4$ & Very Valid \\
$2.6 \leq \mathrm{P}<3.6$ & Valid \\
$1.6 \leq \mathrm{P}<2.6$ & Less valid \\
$1 \leq \mathrm{P}<1.6$ & Not valid \\
\hline
\end{tabular}

\section{RESULTS AND DISCUSSION}

\section{Finding}

\section{Robot Transporter Validation Results}

Three experts validated this robot transporter as learning media for microcontroller subjects. The validation results were analyzed using descriptive quantitative analysis. The quantitative analysis is carried out by calculating the average value given by the validators. Table 7 shows the validation results of the robot transporter as learning media. The first validator gives a score of 3.84, the second validator gives a score of 3.12, and the third validator gives a score of 3.57. The average score from all validators is 3.51 . In the category aspect, this score is a valid category.

Table 7. Validation Results of Robot Transporter

\begin{tabular}{cccc}
\hline No. & Experts & Assessment & Category \\
\hline 1 & Expert 1 & 3.84 & Very Valid \\
2 & Expert 2 & 3.12 & Valid \\
3 & Expert 3 & 3.57 & Valid \\
& Average & 3.51 & Valid \\
& Category Aspect & & Valid \\
\hline
\end{tabular}

\section{Learning Plan Validation Results}

In this research, the learning plan consists of three parts such as syllabus, lesson plan, and student worksheet. The validation of this learning plan was carried out by three experts. From Table 8 , it can be shown that the average score of the syllabus is 3.78 and this score in the category aspect is very valid. The average score of the lesson plan is 3.88 and this score in the category aspect is very valid. The average score of the student worksheet is 3.89 and this score in the category aspect is very valid.

Table 8. Validations Results of Robot Transporter Learning Plan

\begin{tabular}{ccccc}
\hline \multirow{2}{*}{ No } & Experts & \multicolumn{3}{c}{ Learning Plan } \\
\cline { 3 - 5 } & & Syllabus & Lesson Plan & Student Worksheet \\
\hline 1 & Expert 1 & 3.60 & 3.85 & 3.96 \\
2 & Expert 2 & 3.85 & 3.84 & 3.85 \\
3 & Expert 3 & 3.88 & 3.94 & 3.87 \\
& Average & $\mathbf{3 . 7 8}$ & $\mathbf{3 . 8 8}$ & $\mathbf{3 . 8 9}$ \\
& Category Aspect & Very Valid & Very Valid & Very Valid \\
\hline
\end{tabular}

\section{Student Response Results}

Based on the average score of participants, the categorization is as follows (Riduwan, 2003): (1) scale 1 with a range of 0.00 to 1.33 , then the category is Disagree; (2) scale 2 with a range of 1.33 to 2.33, the category is Enough; (3) scale 3 with a range of 2.33 to 3.33, then the category is Agree; and (4) scale 4 with a range from 3.33 to 4.00, the category is Strongly Agree. Table 9 shows the results of the student response. 
Table 9. Student Response Results

Average Score

Category

\begin{tabular}{l} 
Questions \\
\hline 1 The learning media based on the transporter robot is very interesting. \\
2 The learning media based on the transporter robot is very efficient. \\
3 The learning media based on the transporter robot can encourage learning. \\
4 The learning media based on the transporter robot can encourage imagination \\
5 The learning media based on the transporter robot can create new things in \\
microcontroller programming subjects by doing practical work. \\
6 The learning media based on the transporter robot can make students active \\
independently in reasoning knowledge. \\
7 The learning media based on the transporter robot can make students active \\
in questioning activities. \\
8 The learning media based on the transporter robot can make students easily \\
understand the basic concept material in microcontroller programming \\
subjects.
\end{tabular}

9 The learning media based on the transporter robot can make students easily simulate basic concept material in object-oriented programming subjects.

10 The learning media based on the transporter robot can make students learn seriously.

11 The learning media based on the transporter robot can make students serious in paying attention to the media.

12 The learning media based on the transporter robot very effective in helping students understand learning.

13 The learning media based on the transporter robot is very potential in understanding learning.

14 Students better understand the basic concept material in microcontroller programming subjects with the learning media based on the transporter robot.

15 Students prefer to learn basic concept material in microcontroller programming subjects with the learning media based on the transporter robot.

3.33

3.23

3.30

3.27

3.13

2.97

2.97

3.27

Agree

Agree

Agree

Agree

3.28

Agree

3.30

Agree

16 Students increase their knowledge in microcontroller programming subjects

Strongly Agree after using the learning media based on the transporter robot.

17 Students increase their skills in microcontroller programming subjects after using the learning media based on the transporter robot.

18 Teachers and students are more interactive in microcontroller programming subjects after using the learning media based on the transporter robot.

19 Students are more creative after using the learning media based on the transporter robot.

20 The learning media based on the transporter robot make students actively ask questions in microcontroller programming subjects.

21 The learning media based on the transporter robot allows students to share knowledge with friends.

22 The learning media based on the transporter robot allows students to share experiences with friends.

23 The learning media based on the transporter robot make students able to answer teacher questions.

24 The learning media based on the transporter robot is more interesting to use.

25 The learning media based on the transporter robot can make students more enthusiastic in learning.

26 The learning media based on the transporter robot can make student learning outcomes in the cognitive domain on basic concept material higher than before.

27 The learning media based on the transporter robot can make student learning outcomes in the psychomotor domain on basic concept material higher than before.

28 The learning media based on the transporter robot can make students have active discussions between students and teachers.

29 The learning media based on the transporter robot can improve student learning outcomes in the cognitive domain on the subject of basic concepts in microcontroller programming subjects.

30 The learning media based on the transporter robot can improve student learning outcomes in the psychomotor domain on the subject of basic concepts in microcontroller programming subjects.
Agree 
Table 9 shows that for 30 questions for the students there are two responses with the Strongly Agree category and 28 responses with the Agree category. This shows that the transporter robot as learning media able to attracts students to use it in the teaching-learning process in microcontroller subjects.

\section{Discussion}

The research results show that the validation results of the transporter robot as learning media are in the category valid. This is supported with the results of the student responses for question numbers from 1 to 4 and question numbers from 18 to 25 related to the attractiveness of the learning media after the students used the robot transporter. The category of student responses to those questions is 'agree'. This condition is supported by Deiniatur (2019) and Chen et al. (2020) that new media can also make students enthusiastic in following the teaching and learning process in the classroom. This is also in line with the research conducted by Haryawan and Prayogo (2017) which reveals that the use of Arduino-based microcontroller teaching materials can help students gained their learning motivation for microcontroller subjects.

The results of experts' validation for the learning plan consist of the syllabus, the lesson plan, and the student worksheets are in the category valid. Thus, during the process of using learning media, students gave good responses to follow the instructions from the teacher based on the syllabus and the lesson plan. This is shown by the student's response to answer questions from number 10 to 13 that related to the ease of transfer of knowledge using the transporter robot learning media. The category of student responses to those questions is 'agree'. According to Apriyus et al. (2020), learning media can lead to the interconnection between users and learning media with mutual influence and mutual action and reaction between them in helping to convey learning material. According to Budiharto et al. (2017), learning media in the form of robots can be used to learn basic mathematics in elementary students. Learning with robots also provides entertainment for elementary students, so that mathematics lessons become more interesting for elementary students to learn.

As previously mentioned that student worksheet is in the valid category, thus, students can practice and study the learning material of microprocessors through student worksheets. It is supported by student responses for questions number 26 to 30 which contain learning material of microprocessors in the worksheet. Students' responses to those questions are categorized 'agree'. The use of robots as learning media can help students to understand learning material with significant results. According to Ziaeefard et al. (2017), the use of robots can be used to learn STEM in precollege students where learning outcomes show significant results. The results of this study were also in compatibility with research by Akashiba, et al. (2017). It stated that learning applications for collaborative teaching using robots, laptop PCs, sensors, teachers, and students developed with PRINTEPS shown that the implementation of lessons carried out in science classrooms runs well.

\section{CONCLUSION}

The validation results of the robot transporter in the microcontroller subject shows the value of the validity of media quality is 3.89 with the category of very valid. The values of validity on the learning plan that consists of the syllabus, the lesson plan, and the student worksheets are as follows: the syllabus score is 3.78, the lesson plan score is 3.88, and the student worksheets score is 3.89. All these scores are categorized as very valid based on Table 6. For student responses result is category agree. Thus, it can be concluded that the robot transporter can be used in the learning microprocessor. It can be seen that the development of the robot transporter can increase the learning motivation of students majoring in Industrial Electronics Engineering, Al Kholiliyah Vocational High School, Bangkalan, Indonesia.

\section{ACKNOWLEDGMENTS}

The research work was supported in a funding grant issued by the Ministry of Education and Culture under the research agreement task of KEMENDIKBUD 2020, Number B/11633/UN38.9/ LK.04.00/2020. 


\section{REFERENCES}

Akashiba, S., Nishimoto, C., Takahashi, N., Morita, T., Kukihara, R., Kuwayama, M., \& Yamaguchi, T. (2017). Implementation of Teacher-Robot Collaboration Lesson Application in PRINTEPS. Procedia Computer Science, 112, 2299-2308. doi:https://doi.org/10.1016/ j.procs.2017.08.264

Akbar, S. (2013). Instrumen perangkat pembelajaran. Rosdakarya.

Apriyus, D., Rukun, K., Huda, A., \& Marta, S. A. (2020). Validation of media interactive learning in vocational high school. Jurnal Pendidikan Teknologi Kejuruan, 3(1), 64-67. doi:https:// doi.org/10.24036/jptk.v3i1.4423

Baba, A. (2020). A new design of a flying robot, with advanced computer vision techniques to perform self-maintenance of smart grids. Journal of King Saud University - Computer and Information Sciences, 1-10. doi:https://doi.org/10.1016/j.jksuci.2020.07.009

Baharuddin, B., \& Daulay, I. (2017). The development of computer-based learning media. International Journal of GEOMATE, 12(30), 96-101. http://dx.doi.org/10.21660/2017.30. TVET003

Budiharto, W., Cahyani, A. D., Rumondor, P. C., \& Suhartono, D. (2017). EduRobot: Intelligent Humanoid Robot with Natural Interaction for Education and Entertainment. Procedia Computer Science, 116, 564-570. doi:https://doi.org/10.1016/j.procs.2017.10.064

Chen, H., Park, H. W., \& Breazeal, C. (2020). Teaching and learning with children: Impact of reciprocal peer learning with a social robot on children's learning and emotive engagement. Computers \& Education, 150, 1-19. doi:https://doi.org/10.1016/j.compedu.2020.103836

Daryanto, D. (2010). Pembelajaran peranannya sangat penting dalam mencapai tujuan pembelajaran. Gaya Media.

Deiniatur, M. (2019). Developing learning media through Macromedia Flash application for English Phonology class. Journal Smart, 5(1), 45-59. doi:https://doi.org/10.26638/JS.781. $203 \mathrm{X}$

Haryawan, A., \& Prayogo, S. S. (2017). Pengembangan bahan ajar Mikrokontroler berbasis Arduino sebagai media pembelajaran mata kuliah Mikrokontroler di Politeknik Pratama Mulia Surakarta. POLITEKNOSAINS, 16(2), 79-86. Retrieved from http://jurnal.politama. ac.id/index.php/jp/article/view/42

Lanz, M., Pieters, R., \& Ghabcheloo, R. (2019). Learning environment for robotics education and industry-academia collaboration. Procedia Manufacturing, 31, 79-84. doi:https://doi.org/ 10.1016/j.promfg.2019.03.013

Lee, J. -J., Kim, D. -W., \& Kang, B. -Y. (2012). Exploiting child-robot aesthetic interaction for a social robot. International Journal of Advanced Robotic Systems, 9(3), 1-9. doi:https://doi. org/10.5772/51191

Li, J., Barwood, M., \& Rahimifard, S. (2018). Robotic disassembly for increased recovery of strategically important materials from electrical vehicles. Robotics and Computer-Integrated Manufacturing, 50, 203-212. doi:https://doi.org/10.1016/j.rcim.2017.09.013

Mayer, R. E. (2001). Multimedia learning. Cambridge University Press.

Negri, S. P., Basile, V., Valori, M., Gambino, B., Fassi, I., \& Tosatti, L. M. (2019). A modular mobile robotic architecture for defects detection and repair in narrow tunnels of CFRP aeronautic components. Robotics and Computer-Integrated Manufacturing, 55, 109-128. doi:https://doi.org/10.1016/j.rcim.2018.07.011

Riduwan, R. (2003). Dasar-dasar statistika. Alfabeta.

Riduwan, R. (2012). Skala pengukuran variabel-variabel penelitian. Alfabeta. 
Sadiman, A. (2010). Media pendidikan. Raja Grafindo.

Sarwandi, S., Giatman, M., Sukardi, S., \& Irfan, D. (2019). Developing mobile-based project-based learning module for project management courses in vocational education. Jurnal Pendidikan Vokasi, 9(2), 207-216. doi:https://doi.org/10.21831/jpv.v9i2.25947

Sena, A., \& Howard, M. (2019). Quantifying teaching behavior in robot learning from demonstration. The International Journal of Robotics Research, 39(1), 54-72. doi:https:// doi.org/10.1177/0278364919884623

Suryani, N., \& Agung, L. (2012). Strategi belajar mengajar. Ombak.

Ziaeefard, S., Miller, M. H., Rastgaar, M., \& Mahmoudian, N. (2017). Co-robotics hands-on activities: A gateway to engineering design and STEM learning. Robotics and Autonomous Systems, 97, 40-50. doi:http://dx.doi.org/10.1016/j.robot.2017.07.013 